\title{
Chambers of Commerce and Industry
}

\author{
Fahri Özsungur ${ }^{1 *}$ and Himmet Karadal ${ }^{2 *}$ \\ ${ }^{1}$ Adana Science and Technology University, Department of International Trade and Finance, Adana, Turkey \\ ${ }^{2}$ Bolu Abant Izzet Baysal University, Department of Public Relations, Turkey
}

*Corresponding author: Fahri Özsungur, 1Adana Science and Technology University, Department of International Trade and Finance, Adana, Turkey.

Received Date: January 04, 2020

Published Date: January 10, 2020

\section{Introduction}

The chambers of commerce and industry are professional organizations that are committed to revealing the entrepreneurial characteristics of the private sector that offer predetermined services to their members. The legal status of these organizations may vary depending on the countries in which they are established. These organizations, which try to create clusters with initiatives and incentives focused on initiative and innovation, are important for macro and micro-economy. The fact that these organizations revive the private sector, regardless of whether they are subject to private or public law, is not under much research.

In the literature, studies on enterprises and companies are made and the organizational structures of the private sector are examined. Research of professional organizations that bring these structures together and provide economic revitalization will make important contributions to the literature. The examination of the membership structures, organizational structure, the organs of the organization and the relations of the professional organizations that adopt the membership system can provide important benefits in practice. Explaining the benefits of membership and benefits of membership system for members and stakeholders will provide a mirror to professional organizations.
In this study, the historical development of trade and industry, organizational structures, basic benefits, organizations in Turkey, tasks, work areas and membership, the staff structure of the relevant legal regulations are described with the literature review.

\section{Research Methodology}

This study was prepared using a systematic research method. First of all, the professional organizations that adopted the membership system were selected as a current issue. A literature review of these organizations was conducted. The information obtained by defining the research topic was systematically sorted.

During the ranking, topics were created. Coding was used to create the topics. Coding is the process of marking to ensure the integrity of the information obtained as a result of research on a subject. Thanks to the information obtained by coding, related sentences, words, and topics can be brought together. To ensure integrity, the explanations under the headings were revised. Subsequently, the topics were arranged to form a meaningful whole. The results revealed by the literature review were included in the study (Figure 1).
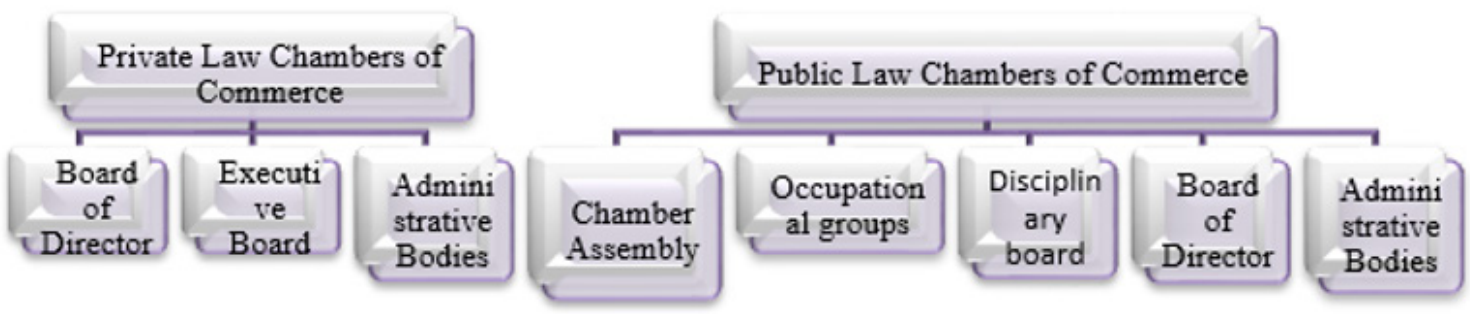

Figure 1: Comparison of Chambers of Commerce and Industry Bodies According to Legal Status. 


\section{Chambers of commerce and industry in Turkey}

Chambers of commerce and industry were clarified with historical development, organization of chambers of commerce and industry in Turkey, tasks, work areas and membership, personnel structure.

\section{Historical development of chambers of commerce and industry}

Its history, which dates back to the 15th century Europe, and the chambers of commerce were in the guild order of merchants in the form of compulsory membership Sturges [1]. American chambers of commerce emerged in the nineteenth century to sustain economic and political interests as the association of trade owners in major cities Friedman [2]. American chambers of commerce were organized in the form of organizations that are effective in sha ping the development and legislative policies of the economy in the private sector Himmelberg [3]. The chambers of commerce, which started to organize from big cities, first concentrated their activities on small enterprises, and entered into efforts for industrialization and rural development since the 1980s, have become an important structure for economic development. Industrialization and developments in production have triggered the formation of the production-oriented organization along with trade so that chambers of commerce and industry have started to form.

In Germany, Austria, the Netherlands, France, Spain, Luxembourg and Italy, Chambers of Commerce and other trade associations are private legal entities with a formal status recognized by the government and by public law and require voluntary membership. This enables the chambers of commerce to have the power to employ a large and professional staff and to have the rights and practices such as criticizing the legal regulations of the government and assisting in the identification of implementation problems Bennett [4-6]. In Japan, different forms of official stateindustry relations have allowed local and sectoral organizations to develop similarly. In the USA, Canada, and the United Kingdom, business organizations do not have formal status. They are voluntary organizations, mostly based on members' resources and staff, and have little ability to control members or to cover a wide area. Therefore, the activity impacts of the chambers of commerce in these countries are limited compared to other countries in which they can influence the external environment. The limited availability of services and resources reduces competitiveness Bennett [4-6], Galambos [7].

The official status of the chambers of commerce and industry, which play an important role in the expansion of the business network and protection of national and international rights and interests of enterprises in Asia, Europe and many parts of the world, is important in terms of whether they are supported by the state or not, and their spheres of influence and the limitations of their activities Hart and Schultze-Zeu [8].
In countries such as the United Kingdom, which have adopted a voluntary system, businesses want to become members of chambers of commerce to access services that they think will provide them with special benefits. It is more beneficial to provide services such as education, social and political networks, fairs, consultancy services that play an important role in the development of enterprises in a continuous manner by a member chamber than purchasing private services from outside. The chambers of commerce provide services to their members by specializing themselves or accessing information according to the characteristics of each business and also making the legal applications necessary for the realization of the needs of the enterprises while providing this service separates the chambers from other organizations. Businesses who desire to operate in the international market have significant contributions from the chambers of industry and commerce in the context of market competition, sectoral risks, financial and legal requirements. Olson [9] put forward the idea that the solution to common problems of enterprises can be realized with services that have collective and regulatory functions.

In the study conducted with 150 firms in the UK, it was found that $45.3 \%$ of the companies were members of the chamber of commerce to purchase a useful service, $18.9 \%$ of them were in contact with other enterprises and $17 \%$ of them were members of the chamber of commerce [10].

\section{Chambers of commerce and industry}

Chambers of Commerce and Industry's legal status was regulated with the Law No. 5590 dated 15/03/1950 published in the Official Gazette (No. 7457), the Law of the Union of Chambers and Commodity Exchanges of Turkey, and the Chambers and Commodity Exchanges (Law No. 5174) which regulates the principles of establishment and operation of Chambers of Commerce and Industry.

\section{Establishment of chambers of commerce and industry}

According to the fifth article of Law No. 5174, the chambers are established in the provinces with the decision of the Ministry upon the positive opinion of The Union of Chambers and Commodity Exchanges of Turkey (UCCET). In order to establish a chamber in a province, at least one thousand merchants registered in the trade registry must submit a written application to UCCET. In order for the Chamber of Industry to be established independently, more than half of the industrialists within the borders of the province where the chamber will be established require a written request (Law No. 5174, Art. 5). Since the necessary conditions for the establishment of an independent chamber of industry are met, the name of the legal entity of the Chamber of Commerce and Industry becomes the Chamber of Commerce. In order to establish geographical region chambers, more than half of the number of members in the provinces included in these regions must apply to UCCET formally or decisions of two-thirds of the total number of members of the chamber council of each province and the decision of the Ministry 
with the positive opinion of UCCET are required (Law No. 5174, Art. 5 ).

\section{Tasks of chambers of commerce and industry}

The basic tasks of the chambers are to meet the common demands and needs of its members, to facilitate their professional activities, to ensure the development of the profession in accordance with the general interests, and to ensure the honesty and trust of the members among themselves and in their relations with the public. The chambers are required to maintain professional solidarity, ethics, and discipline, and to fulfill the duties assigned to it by other law provisions (Law No. 5174, Art. 4). To carry out the necessary activities for the development of trade and industry, to contribute to the country's economy, to make all the information obtained on these issues open to the members and the public, to convey the information and documents required by the public in the desired time and manner, to provide the members with the necessary opportunities and opportunities to develop themselves professionally and commercially, providing the infrastructure, and making proposals, opinions and requests from the official institutions on issues related to the professional activities are among the duties of the chambers. To make decisions about the obligatory professional rules of the members of the chambers and to organize the fairs in Turkey and abroad to ensure the interaction of the business network.

\section{Working areas of chambers of commerce and industry}

The chambers operate at provincial borders (Law No. 5174, Art. 6). With the proposal of the chamber's board of directors and the decision of the council, the branches in the districts and representative offices in the absence of the branches can be established by the chambers. Merchants registered in the trade registry and industrial individual and legal persons are required to register in the chambers where their business and branch offices are centered (Law No. 5174, Art. 9). Compulsory membership shows that the chambers of commerce and industry, which is a public professional organization according to Turkish Law, are public legal entities. The necessity of membership may increase the expectations of the chambers. The perception of service expectations resulting from the joint evaluation of the advantages and disadvantages of membership enables the chamber to improve its adoption behavior Ottenbacher and Harrington[11]. Therefore, each member's service expectation and the behavior that he/she will develop depends on the result to be obtained in the gain/loss comparison.

\section{Personnel structure of chambers of commerce and industry}

In the chambers of commerce, three legal personnel are employed. The first one is the chamber employees employed according to the Law of "Chambers of Commerce and Industry, Chambers of Commerce, Chambers of Industry, Chambers of Shipping, Commodity Exchange and The Union of Chambers of Commerce, Industry, Shipping and Commodity Exchanges of Turkey" (repealed Law No. 5590).
The second is the contracted personnel subject to the code of Chambers of Commerce and Industry, Chambers of Commerce, Chambers of Industry, Chambers of Shipping, Commodity Exchange and The Union of Chambers of Commerce, Industry, Shipping and Commodity Exchanges of Turkey which was accepted by the decision of the Council of Ministers (18.5.1983 dated, No. 83/6620) and was published in the Official Gazette (5.8.1983 dated, No. 18126) and was entered into force on 1.9.1983.

The third is the contracted personnel subject to the Labor Law (Law No. 4857) in accordance with the Law of the Union of Chambers and Commodity Exchanges of Turkey and Chambers and Exchanges (Law No. 5174, Art. 73). Due to three different legal structures, the wage and personal rights of the employed personnel differ.

\section{Organizational Structure of Chambers of Commerce and Industry}

The bodies of the chambers of commerce and industry, which have the status of private law, are generally the general assembly or the administration, supervision and administrative body. This structure depends on the country of the chamber, the type of company and the legal order to which it is subject. For instance, in the UK and the United States, chambers of commerce are organized as companies, and the board of directors elected at the general meeting is the executive and supervisory body of the chamber. The executive board functions under the board of directors. The top executives and other bodies forming the administrative structure serve under the board of directors and the executive board. The bodies of each chamber of commerce and industry that form the administrative structure are also different Willard [12] Cargill [13].

The bodies of the chambers of commerce and industry which have the status of public law are the chamber council and the board of directors in general. Professional groups and disciplinary boards are among these bodies. Like chambers with the status of private law, chambers with the status of public law vary from country to country, depending on the legal order to which it is subject. The bodies of each chamber of commerce and industry, which constitute the administrative structure, may differ, although they are subject to the same country and legal status. The comparison scheme of the bodies of the chambers of commerce and industry according to public and private law status is shown in Figure 1, Katz [14].

\section{Occupational groups in chambers of commerce and industry}

Occupational groups are sectoral groups composed of chamber members according to the distinction made regarding occupations. These groups consist of a certain number of members for a certain period of time. Occupational groups perform the tasks assigned to them. They provide information flow to the room by conducting sectoral researches about occupations. Thus, it enables the room to develop itself in a sectoral and professional sense and to become a learning organization. Changing technological infrastructures, developing economy, competitiveness in the external environment, 
sectoral disputes, and problems, Occupational problems are determined instantly by occupational groups and in-chamber information flow is provided by these groups. It ensures that the chamber is specialized in terms of occupations and sectors and that the management is conducted within the framework of this expertise in terms of ensuring the formation of the assembly. The opinions of the occupational groups are taken in order to solve the problems such as unemployment, economic bottleneck, glass ceiling, the price of products and services, quality, marketing, advertising, unfair competition. If professional technical information is requested from the chambers by the courts and official institutions, the expert opinion of occupational groups is obtained Arthur [15]

\section{Chamber assembly in chambers of commerce and industry}

There are chamber assemblies in which members of chambers of commerce and industry subject to public law are represented. These assemblies consist of members to be elected by the professional groups for a certain period. The chamber assemblies, organized in the form of chairman, vice-chairman and other members, ensure the administrative organization of the chamber by the election of the members of the board of directors. Chamber assemblies often emerge in chambers subject to public law status. Since the chambers subject to private law status are organized as companies, associations, and foundations, the top management body is generally emerging as the management body Koster [16]. Chamber assemblies are the highest management and inspection body of the chamber. However, the task of active implementation of administrative procedures is assigned to the board of directors. It is among the tasks of the chamber assembly to take the necessary legislative directives and implementation decisions for the management and operation of the chamber and to carry out the audit.

\section{Board of directors in chambers of commerce and industry}

Chamber board of director members are part-time volunteers employed by local chambers of commerce and industry. These volunteers do not face as much economic difficulties as paid employees when they quit. Chamber board of director members are subject to both internal and external motivation. Since board members are voluntary, they are subject to intrinsic motivation through personal development Miller [17], self-realization and professional development Anderson and Moore [18] self-realization Steers and Porter [19] and self-sacrifice (Dawley, Stephens and Stephens, 2005).

The chamber board of director members provides indirect economic benefits through experience and interactions with the community, business, and social networking and recognition. The fact that a businessman engaged in commerce enters the board of directors of the chamber of commerce voluntarily provides the competence to overcome sectoral problems in local business networks Dawley [20]. The development of the economy by domestic and international fairs and trade agreements can contribute to making significant progress in the field of import and export, and individual relations with the public, and to contribute to the solution of existing problems.

The extent to which the employee or member of the organization reflects itself with the values and mission of the organization is related to normative commitment Meyer and Allen [21]. The impact of this type of commitment, which is found to be positively related to job satisfaction and performance, on voluntary board members is significant Meyer, Stanley, Herscovitch and Topolnytsky [22]. The members of the board of directors perform their voluntary work in the chamber management where they are elected based on representation, by adopting the value and mission of the chamber organization. In the next elections, the re-election situation is realized by considering job satisfaction, performance, degree of adoption of the organization's value and mission. In the first election, personality traits, business, and social networking elements are predominantly influential, while in other elections the indicators and outcome of normative commitment are effective. As the bond and cohesion with the organization increases, the member of the board of directors begins to take the volunteer status to the axis of responsibility. The sense of responsibility forces the individual to adopt certain obligations and ethical principles. This situation results in the fact that ethical leadership features are partially attributed to the individual. In compulsory and legal memberships, this situation differs from the fact that it will create compelling effects on perception. Obligations can create reluctant tendencies if they do not occur with adoption behavior. This can lead to poor performance and compatibility issues.

Board members of learning organizations such as chambers of commerce and industry have an intrinsic drive through selfrealization and sacrifice (Steers and Porter, 1975). They are also under the influence of internal motives such as professional and personal development (Miller, 1985; Anderson and Moore, 1978). These learning organizations make significant contributions to the organization and its members through social interaction, close relations with members.

\section{Disciplinary board in chambers of commerce and industry}

Disciplinary committees are set up in order to punish chamber members regarding their unethical behaviors in terms of occupation. These boards ensure the order among the members of the chamber and that the rules set by the chamber are followed. The disciplinary board works for the implementation of the necessary sanctions in case of any violation of the current legal order by the directives and decisions determined by the chamber council. The disciplinary board is not a judicial body, but a detection and investigation body. The information and documents obtained as a result of the researches and investigations and opinions and thoughts are presented to the chamber council which is the final decision body of the chamber Bennett, Krebs and Zimmermann [23]. 


\section{Legal Status of Chambers of Commerce and Industry}

Chambers of commerce and industry are private and public law legal entities. There are some differences in legal status in terms of organizational functioning as can be seen in Table 1. Facilitation of partnership between business world and government, the greater political impact for the enterprise, independence for the enterprise and ease of long-term planning for chambers and the availability of adequate resources to ensure high quality are the advantages of chambers of commerce and industry with public law status. Bureaucracy, organizational image problems and the limited independence of the chambers can lead to disadvantages such as submission to state control and less service provision. The fact that the status of public law is equipped with the power of sanction can give the power to the chambers, but it can also turn away from being a customer-oriented, innovation-oriented organization. Chambers subject to private legal status may experience a lack of political influence, a lack of government support and counseling Fallon and Brown [24], Fallon and Brown [25]

Table 1: Comparison of Main Public Tasks According to Private and Public Law Systems.

\begin{tabular}{|c|c|c|c|c|c|c|c|}
\hline \multirow{2}{*}{ Public Tasks } & \multicolumn{2}{|c|}{ Private Law } & \multirow{2}{*}{\begin{tabular}{|c|} 
Mixed Law \\
Japan \\
\end{tabular}} & \multicolumn{4}{|c|}{ Public Law } \\
\hline & England & USA & & Germany & France & Netherlands & Turkey \\
\hline $\begin{array}{l}\text { To promote the economic interests of local } \\
\text { businesses. }\end{array}$ & No & No & Yes & Yes & Yes & Yes & Yes \\
\hline $\begin{array}{l}\text { To provide information, advice, and support } \\
\text { to businesses }\end{array}$ & No & No & Yes & Yes & Yes & Yes & Yes \\
\hline Publication of commercial documents & No & No & Yes & Yes & Yes & Yes & Yes \\
\hline To manage business records & No & No & Yes & Yes & Yes & Yes & Yes \\
\hline $\begin{array}{l}\text { Owning and managing infrastructure, and } \\
\text { other facilities }\end{array}$ & No & No & No & No & Yes & No & Yes \\
\hline $\begin{array}{l}\text { Managing educational institutions and } \\
\text { providing training }\end{array}$ & No & No & Yes & Yes & Yes & No & Yes \\
\hline $\begin{array}{l}\text { Organizing short training courses, } \\
\text { improving business skills and conducting } \\
\text { relevant exams. }\end{array}$ & No & No & Yes & No & No & No & Yes \\
\hline $\begin{array}{l}\text { Arbitration and credit valuation tests in } \\
\text { commercial affairs }\end{array}$ & No & No & Yes & No & No & No & No \\
\hline $\begin{array}{l}\text { To promote trade-related development of } \\
\text { the tourism industry }\end{array}$ & No & No & Yes & No & No & No & No \\
\hline
\end{tabular}

Resource: Heseltine, 2012; Bennett, 2011a, 2011b.

The development of the local economy, educational supports, responding to the demands of the members, providing effective service with advanced lobby power are among the benefits of the compulsory membership system. However, there may be conflicts of interest regarding the services provided to the members, and the necessity of being a member may cause negative relations arising from the obligation to the chamber-member relationship (Table 2).

Table 2: Comparison of Chambers of Commerce by Legal Status.

\begin{tabular}{|c|c|}
\hline Chambers Subject to Public Law & Chambers Subject to Private Law \\
\hline Mandatory membership from defined group & Voluntary membership, open to all \\
\hline Membership fees are considered as 'tax'. & $\begin{array}{l}\text { Based on election and commitment, understanding of the cost of } \\
\text { membership is dominant }\end{array}$ \\
\hline Includes legally defined businesses. & Includes memberships as a result of the election. \\
\hline It has a national network in every field & Generally, the level of the network is low in rural areas. \\
\hline On an irregular geographic basis, it is usually structured at the 'state' level & $\begin{array}{l}\text { They are structured in a variable geography depending on local identity } \\
\text { and sense of community. }\end{array}$ \\
\hline They are big organizations & $\begin{array}{l}\text { They have the size of the organization which changes according to } \\
\text { member loyalty. }\end{array}$ \\
\hline $\begin{array}{l}\text { They have large staff resources and services provided by public funding to } \\
\text { meet defined public needs. }\end{array}$ & $\begin{array}{l}\text { They have sales and contractual revenue and services to meet commercial } \\
\text { and enterprise demands. }\end{array}$ \\
\hline They are subject to public audit and the members cannot disable it. & $\begin{array}{l}\text { Members are free to act in the issue of audit. The organization may face } \\
\text { frustration restrictions as a disadvantage of this freedom. }\end{array}$ \\
\hline $\begin{array}{l}\text { Secure access to government communications is possible. However, this } \\
\text { situation can be ignored. }\end{array}$ & The government can choose when to consider the organization. \\
\hline Bureaucratic, often causing low domestic policy conflict & $\begin{array}{l}\text { They are entrepreneurial and trade-oriented, have potential implications } \\
\text { for greater variability in adherence to organizational policy. }\end{array}$ \\
\hline
\end{tabular}

Resource: Bennett, 2011a, 2011b [4,5]. 
The legal status of the chambers, whether membership is compulsory or optional, makes the chambers' representation and legitimacy issues clear. Chambers subject to private law and subject to voluntarism demonstrate their legitimacy. Compulsory and legal membership systems, on the other hand, are not representative in terms of the legitimacy of the chambers (Fallon and Brown, 1999; Fallon and Brown, 2000) (Table 3).

Table 3: Similarities and Differences Between Chambers of Commerce and Industry.

\begin{tabular}{|c|c|c|c|}
\hline Structural Aspects & U.K. & Germany \& France & Turkey \\
\hline Legal Status & Private & Public & Kamu \\
\hline Membership & Voluntary & Legal & Completely \\
\hline Scope of Work & Partially & Greatly formal & Greatly formal \\
\hline Finance & Private / unofficial & Generally large & Generally large \\
\hline Organization Size & Usually small & Public control & Public control \\
\hline Quality Control & Voluntary accreditation & High & High \\
\hline Status and Recognition & Usually low & All regions & Not possible \\
\hline National Recognition & Insufficient & Not possible & Yes \\
\hline Local Overlap/Conflict & Possible & Yes & Yes \\
\hline Legal Task & No & Yes & Yes \\
\hline Autonomous Tasks & Yes & Yes & Basic \\
\hline Business Advice and Information & Yes & High & High \\
\hline Representative Role & Limited & & \\
\hline $\begin{array}{l}\text { The role of local economy in terms } \\
\text { of development }\end{array}$ & Little & & \\
\hline
\end{tabular}

Resource: adapted from Bennett et al. [23]; Fallon \& Brown [24].

The reason for similarities with Turkey, Germany, and France, that considering these countries' laws and institutions with regulating the Laws and Codes regarding Chambers of Commerce and Industry.

\section{Basic Functions of Chambers of Commerce and Industry}

Chambers of commerce and industry are professional organizations formed by enterprises. The chambers provide basic benefits, including the reputation of their members, social benefit, healing, satisfaction and perceived value.

\section{Providing reputation}

Chambers are the entities that can ensure their members to provide a reputation in the eye of their customers in the business world. Many members expect special benefits from the chambers. One of these benefits is providing the reputation through the chambers. Businesses register with the chambers of commerce and industry to gain recognition in the business environment, expand their network, and ensure reliability for customers. Membership in the chamber provides a reputation in the business environment Pearre [26].

\section{Social benefit}

The chambers of commerce and industry provide benefits such as supporting social formations, development of social networks, education, seminars, scholarships, financial support, and sharing of data that may benefit the society. The development of social relations between people is also reflected in the business network. These organizations, which are constantly learning and whose communication network is up to date, can transform the social network into a business network with the activities they perform. Monthly newsletters, sponsorships, advertising and marketing services and social and business networks are in constant contact. The chambers organize fairs to increase the communication and interaction of their members with each other. Fairs are important for expanding the national and international business network, getting to know the competitors closely, learning the market, getting sectoral information and recognizing the cultural and social characteristics of the customers Hill and Lynn [27].

The chambers are non-profit professional organizations and take the necessary initiatives for the development of the economy. Chambers of public or private legal entities play an important role in communicating economic or social problems to government officials. The fact that a member from occupational groups is the president of the chamber reflects the image of the chamber as a leader and provides the necessary initiatives to solve the problems effectively and efficiently through social relations. The fact that the chambers of commerce present the social and business network in a transparent way provides assistance to individuals and nongovernmental organizations that will benefit from the network. The social benefit network offers interaction, psychological benefits, as well as strategic innovations, new initiatives, job opportunities and other opportunities for small businesses and individuals Faems, Van Looy and Debackere [28], Newton [29].

\section{Improvement benefit}

Businesses need credit and financial support for sustainable competition and the necessary funding. Chambers of commerce and industry provide the means to access these sources of funding. The chambers balance the risks associated with trust and prevent 
the negative impact of competition on cooperation Bunger [30]. Due to gaining competitive advantage by small businesses and access to national and international markets through fairs and events, significant improvements are provided in economic and developmental terms (Newton, 1977).

\section{Satisfaction and perceived value}

The total benefits and set goals achieved through the exchange of information and the sharing of resources require the establishment of a specific order within the organization and the implementation of the necessary initiatives for the purposes. The fact that the total benefit is above the individual benefit brings with it the problem of personal and total satisfaction. Total benefits and interests can be realized through the organization. This situation causes perceived value, organizational climate, satisfaction, and commitment to the organization Tsasis [31]. Chambers have an important role in creating values such as establishing common identity and discovering common interests Snavely and Tracy [32].

\section{Discussion}

Crawford and Branch [33] revealed that rural chambers represent a unique example of emerging public-private partnerships that challenge the traditional commercial logic of chambers of commerce. Fallon and Brown (1999) discussed and compared various aspects of the UK, French, and German Chambers of Commerce in order to assess whether the transition to public law status for the UK Chambers of Commerce was in the best interests of England.

Meyer and Allen (1997) tested the multidimensionality of organizational commitment of voluntary chamber members and the effect of organizational commitment on board member roles using data from 616 participants in 116 chambers in 36 states using Confirmatory Factor Analysis.

Contrary to previous research using Meyer and Allen (1997), which focuses on salaried employees, Dawley, Stephens, and Stephens (2005) found that normative, emotional, and continuity commitment are three distinct structures valid for voluntary employees and that these components have a positive impact on the roles of board members.

According to a study by Giurgiu [34] Manciu, and Lese (2016) in order to demonstrate the role of the new ways of communication in the training courses of the Chamber of Commerce, the need to create a distinctive market appeal for a new design and the transformation and modernization of teaching methodology was identified.

According to a study conducted by Alageeli and Aalyateem [35] which aims to determine the role of implicit knowledge in developing human resources in the Jeddah Chamber of Commerce and Industry; they found that managers in the chamber of commerce and industry need to know how to effectively manage employees and their favorite learning techniques, and understand what motivates them to work seriously. The authors emphasized that knowledge is no longer a power in the computer and internet age, that knowledge is difficult to apply, and that information management focuses primarily on people, procedures and modern techniques. This study reveals the role of human resource management, learning and information support practices in the chambers of commerce and industry, and the promotion of human resources to a level that helps commercial organizations to live and continue successfully.

\section{Conclusion}

Chambers of commerce and industry are professional organizations that provide members with reputation, social benefit, improvement, satisfaction, and perceived value benefit. These organizations provide their members with the necessary incentives and support to gain a competitive advantage, provide financial support to the economic recovery, provide a network and help in the search for new markets. Fairs, inter-state trade relations, entry into international markets provide an important element of trust to financial companies. Despite these benefits, the importance of the chambers of commerce and industry, which has not been sufficiently researched in the literature, for today's economy is indisputable.

Chambers of commerce and industry, which differ from country to country, have three basic statuses: public, private and mixed law. The private law in the UK and the US, the mixed law in Japan, Germany, France, the Netherlands and the public law status in Turkey are applied. The power brought by the organization subject to public law can push businesses to larger markets. There is a more local structure in the chambers of commerce and industry subject to private law. The support of these professional organizations by the power of the public sector can undoubtedly take the competitive advantage of enterprises to a higher level. The reflection of the competition between the chambers subject to private law to the members may interfere with the spirit of entrepreneurship. Therefore, it is recommended to adopt a structure that will include the positive aspects of private and public law for the chambers of commerce and industry.

Investigation of chambers of commerce and industry on organizational behavior, institutional structure, quality management, accreditation and service quality will contribute to the literature. It is recommended to conduct researches in this direction for future studies. The chambers of commerce and industry, which stimulate the private sector, play an intermediary role in economic developments and provide significant networking, should be strengthened in developing countries.

\section{Conflict of Interest}

No conflict of interest.

\section{Acknowledgement}

None.

\section{References}

1. Sturges KM (1915) American chambers of commerce. Department of political science of Williams college, No. 4. 
2. Friedman LM (1947) The first chamber of commerce in the United States. Business History Review 21(5): 137-143.

3. Himmelberg RF (1968) Business, Antitrust Policy, and the Industrial Board of the Department of Commerce, 1919. Business History Review 42(1): 1-23.

4. Bennett B (2011a) Testing times for business partners in regional and local development: the past and future of chambers of commerce. Territory, Politics and Governance. Regional Studies Association, UK, NO. 284.

5. Bennett RJ (2011b) Local Business Voice: The History of Chambers of Commerce in Britain, Ireland, and Revolutionary America. London.

6. Bennett RJ (1996) The Logic of Local Business Associations: An Analysis of Voluntary.

7. Galambos L (1965) Competition and Cooperation: the emergence of a national trade association. John Hopkins University Press, Baltimore, USA.

8. Hart JA, Schultze Zeu D (1995) U.S. Business and Today's Germany: A Guide for Corporate Executives and Attorneys. London: Greenwood Publishing Group.

9. Olson M (1971) The Logic of Collective Action: public goods and the theory of groups (second edition). Cambridge, Mass: Harvard University Press.

10. Heseltine L (2012) No Stone Unturned: Chamber of Commerce International Comparisons UK: Crown, pp. 1-42.

11. Ottenbacher MC, Harrington RJ (2009) The product innovation process of quick-service restaurant chains. International Journal of Contemporary Hospitality Management 21(5) :523-541.

12. Willard CD (1899) A History of the Chamber of Commerce of Los Angeles, California: From Its Foundation. Los Angeles, California: Kingsley-Barnes \& Neuner.

13. Cargill W (1840) Address of William Cargill, Esq. to the South Shields Chamber of Commerce. London: T. Brettell. Chambers of Commerce. Journal of Public Policy 15(3): 251-279.

14. Katz A (2015) The Influence Machine: The U.S. Chamber of Commerce and the Corporate Capture of American Life. Random House Publishing Group. New York.

15. Arthur JW (2016) The Seventeenth Highland Light Infantry (Glasgow Chamber of Commerce Battalion) (WWI Centenary Series). UK.

16. Koster FJ (1918) Law and Order and the San Francisco Chamber of Commerce: An Address. California: Greater San Francisco Chamber of Commerce.

17. Miller LE (1985) Understanding the motivation of volunteers: An examination of personality differences and characteristics of volunteers paid employment. Journal of Voluntary Action Research 14(2-3): 112122.

18. Anderson JC, Moore LF (1978) The motivation to volunteer. Journal of Voluntary Action Research 4: 120-125.
19. Steers RM, Porter LW (1975) Motivation and work behavior. McGrawHill, New York.

20. Dawley DD, Stephens RD, Stephens DB (2005) Dimensionality of organizational commitment in volunteer workers: Chamber of commerce board members and role fulfillment. Journal of Vocational Behavior 67(3): 511-525.

21. Meyer JP, Allen NJ (1997) Commitment in the workplace: Theory, research, and application. Thousand Oaks, CA: Sage Publications.

22. Meyer JP, Stanley DJ, Herscovitch L, Topolnytsky L (2002) Affective, continuance, and normative commitment to the organization: A metaanalysis of antecedents, correlates, and consequences. Journal of Vocational Behavior 61(1): 20-52.

23. Bennett RJ, Krebs G, Zimmermann H (1993) Chambers of Commerce in Britain and Germany and the Single European Market. London: AngloGerman Foundation.

24. Fallon G, Brown RB (1999) Public law status Chambers of Commerce: does Britain need them. Journal of Small Business and Enterprise Development 6(3): 287-298.

25. Fallon G, Brown RB (2000) Does Britain need public law status Chambers of Commerce. European Business Review 12(1): 19-27.

26. Pearre SW (2007) A Case Study of Interest Group Propaganda. Madison: University of Wisconsin. The Chamber of Commerce of the USA.

27. Hill C, Lynn L (2003) Producing human services: Why do agencies collaborate? Public Management Review 5(1): 63-81.

28. Faems D, Van Looy B, Debackere K (2005) Interorganizational collaboration and innovation: toward a portfolio approach. Journal of Product Innovation Management 22(3): 238-250.

29. Newton RC (1977) German Buenos Aires, 1900-1933: Social Change and Cultural Crisis. University of Texas Press, USA.

30. Bunger A (2013) Administrative coordination in nonprofit human service delivery networks: the role of competition and trust. Nonprofit and Voluntary Sector Quarterly 42(6) :1155-1175.

31. Tsasis P (2009) The social processes of interorganizational collaboration and conflict in nonprofit organizations. Nonprofit Management and Leadership 20(1): 5-21.

32. Snavely K, Tracy M (2002) Development of trust in rural nonprofit collaborations. Nonprofit and Voluntary Sector Quarterly 31(1):62-83.

33. Crawford B, Branch J (2015) Interest plurality and institutional work: An ethnography of rural community organizing. Journal of Organizational Ethnography 4(1): 98-116.

34. Giurgiu AM, Manciu L, Lese L (2016) Technological Development - a Tool for Social and Economic Impact of the Chamber of Commerce and Industry of Mures County. Procedia Technology 22:1092-1099.

35. Alageeli OM, Abdullah Aalyateem AM (2015) The role of the tacit knowledge in developing the human resources: Critical analytical study of the knowledge centre in the industrial commercial chamber in Jeddah, the Kingdom of Saudi Arabia. Procedia Computer Science 65: 469-478. 